\title{
PENGEMBANGAN PROSES INAKTIVASI ENZIM POLIFENOL OKSIDASE UNTUK PRODUKSI TEH HIJAU BERKATEKIN TINGGI
}

\author{
Mohamad Endy Yulianto ${ }^{1}$, Fahmi Arifan', Didik Ariwibowo ${ }^{2}$, Indah Hartati ${ }^{3}$ \\ dan, Dewi Mustikaningtyas ${ }^{4}$ \\ ${ }^{1}$ Jurusan Teknik Kimia PSD III Teknik, UNDIP Semarang \\ ${ }^{2}$ Jurusan Teknik Mesin PSD III Teknik, UNDIP Semarang \\ ${ }^{3}$ Jurusan Teknik Kimia Universitas Pandanaran Semarang \\ ${ }^{4}$ FMIPA Universitas Negeri Semarang \\ E-mail: endy_y@yahoo.com
}

\begin{abstract}
ABSTRAK
Teh merupakan bahan minuman penyegar alami yang menyehatkan karena di dalamnya terkandung senyawa katekin yang merupakan senyawa bioaktif yang dapat menghambat pertumbuhan sel kanker, mengurangi kemungkinan timbulnya penyakit jantung, darah dan pembuluh darah, menyehatkan pencernaan makanan, mulut dan gigi serta beberapa penyakit infeksi lain. Oleh karena itu kadar katekin tinggi di dalam teh sangat diharapkan. Untuk memperoleh kadar katekin tinggi harus menghilangkan proses oksidasi polifenol secara enzimatik pada saat pengolahan daun teh. Untuk keperluan itu dirancang suatu proses dan sistem pemroses yang mendukung kondisi pengolahan tersebut. Dasar perancangan yang dipilih adalah inaktivasi enzim polifenol oksidase dengan cara steaming. Teh yang dihasilkan diharapkan merupakan teh berkatekin tinggi yang selain dapat langsung dikonsumsi dapat pula dijadikan bahan baku bubuk katekin untuk preparat dietary food dan fungctional food atau obat. Kajian sistem pemroses ini melibatkan variabel-variabel persen uap panas yang digunakan, kapasitas daun teh dan spray uap air. Parameter yang akan diamati adalah temperatur sistem, kadar katekin, kadar air, dan kelembaban sistem proses yang merupakan fungsi waktu. Hasil proses steaming daun teh menunjukkan bahwa pada temperatur $90^{\circ} \mathrm{C}$, diperoleh katekin dengan kadar relatif tinggi. Hasil kajian juga menunjukkan bahwa kelembaban $70 \%$ didapatkan kadar katekin relatif tinggi dengan kadar air relatif rendah.
\end{abstract}

Kata Kunci: Steaming; teh hijau

\begin{abstract}
Tea is a natural healty beverage because of catechin content which is a bioactive matter that can retard cancel growth, heart desease, blood and nerves, making healthy for mouth, teeth and some other infection. Therefore, high catechin in tea would be needed. To Obtain high catechin content it must eliminate enzymatically oxidation process of polyphenol during tea manufacturing. Thus, it was created a process and processing system which sustain the process. The basic design was inactivation of polyphenol oxidase enzyme by steaming. It wishes a high catechin green tea product that can either be directly as a beverage or as a catechin powder for dietary food and functional food or medicine. The variables of this study were percentage of steam, tea leaves feeding and humidity. The investigated parameters were temperature, catechin content, moisture content, and humidity as time function. The result was that at $90^{\circ} \mathrm{C}$ yielded high catechin. The study shows that at $70 \%$ humidity yielded higher catechin and lower moisture content.
\end{abstract}

Keywords: Green tea; Steaming

\section{PENDAHULUAN}

Teh sebagai bahan minuman penyegar dan menyehatkan merupakan salah satu komoditi unggulan perkebunan Indonesia. Areal teh Indonesia seluas 157.000 ha terdiri atas $54 \%$ perkebunan rakyat, $24 \%$ perkebunan besar negara, dan $22 \%$ perkebunan besar swasta.

Pasar teh dunia yang dibayangi gejala kelebihan pasokan dan biaya produksi yang cenderung meningkat, mengharuskan para produsen teh untuk meningkatkan daya saing dan nilai 
tambah. Masalah lingkungan telah ikut mendorong berkembangnya segmen pasar baru bagi produk teh yaitu konsumen yang menghendaki produk ramah lingkungan dan menyehatkan. Aspek kesehatan teh disorot tajam beberapa tahun terakhir ini sejalan dengan kecenderungan masyarakat mengkonsumsi makanan atau minuman substitusi sebagai imbangan diet kaya lemak dan kolesterol (Ariwibowo, dkk 2005., Yulianto, dkk., 2006).

Katekin $\left(\mathrm{C}_{6} \mathrm{H}_{6} \mathrm{O}_{2}\right)$ dalam teh merupakan komponen utama yang mendominasi sekitar $30 \%$ berat kering teh, ditunjukkan pada Tabel 1 (Bokuchava dan Skobeleva, 1969; Lunder, 1989; Graham, 1992; Price dan Spitzer, 1993; Wang dan Helliwell, 2000). Katekin merupakan kerabat tanin terkondensasi yang juga sering disebut polifenol karena banyaknya gugus fungsi hidroksil yang dimilikinya. Katekin merupakan senyawa utama yang menentukan mutu, baik cita rasa, kenampakan, maupun warna air seduhan (Graham, 1992). Kandungan katekin pada pucuk tanaman teh (Camellia sinensis) varietas assamica lebih banyak dibandingkan varietas sinensis (Yamanashi, 1995). Namun demikian, varietas sinensis memiliki aroma yang lebih baik karena memiliki kandungan asam amino lebih tinggi. Tanaman teh yang dibudidayakan di Indonesia hampir $100 \%$ merupakan varietas assamica. Pucuk teh yang dihasilkan $80 \%$ diolah menjadi teh hitam, sedangkan sisanya diolah menjadi teh hijau. Teh hitam lebih sedikit mengandung katekin daripada teh hijau karena dalam proses pengolahan teh hitam dirancang agar katekin mengalami oksidasi untuk memperbaiki warna, rasa, dan aromanya.

Efek menyehatkan pada teh terletak pada senyawa katekin yang dikandungnya (Copeland et al., 1998; Wanasundara dan Shahidi, 1998; Zandi dan Gordon, 1999; Nwuha et al., 1999; Wang dan Helliwell, 2000; dan Sava et al., 2001). Penelitian dengan teh hijau Jepang membuktikan bahwa katekin dapat mengurangi resiko kejangkitan berbagai penyakit seperti mengurangi resiko kanker, menjaga kesehatan jantung, bersifat anti oksidan, anti mikroba, bahkan mampu memperpanjang masa menopouse dan lain-lain (Oguni, 1993; Bruneman, 1991; Chen, 1991; Fujiki, 1991; Fung, 1991; Hayatsu, 1991). Menurut Bambang (1995, 1996) katekin pada daun teh Indonesia lebih banyak daripada katekin daun teh Jepang, sebab itu potensi menyehatkan teh Indonesia diduga lebih tinggi. Keunggulan ini membuka peluang bagi industri teh Indonesia untuk memproduksi teh hijau berkatekin tinggi sebagai bahan baku preparat katekin dan functional food yang mulai populer pemakaiannya saat ini.

Tabel 1. Komponen utama katekin daun teh segar

\begin{tabular}{|c|c|}
\hline Komponen & $\begin{array}{c}\text { Kadar katekin (\%) } \\
\text { bk) }\end{array}$ \\
\hline (+)-Katekin & $1-2$ \\
\hline (-)-Epikatekin & $1-3$ \\
\hline (-)-Epikatekin galat & $3-6$ \\
\hline (+)-Gallokatekin & $1-3$ \\
\hline (-)-Epigallokatekin & $3-6$ \\
\hline $\begin{array}{c}\text { (-)-Epigallokatekin } \\
\text { galat }\end{array}$ & $7-13$ \\
\hline Total & $16-30$ \\
\hline
\end{tabular}

Sumber: Bokuchava dan Skobeleva, 1969; Lunder, 1989; Graham, 1992; Price dan Spitzer, 1993; Wang dan Helliwell, 2000

Produksi teh hijau pada prinsipnya dilakukan dengan menginaktivkan enzim polifenol oksidase yang berada dalam sitoplasma daun teh. 
Selama ini cara inaktivasi enzim polifenol oksidase yang digunakan untuk memproduksi teh hijau Indonesia adalah cara panning (penggarangan). Ditinjau dari segi ekonomi dan teknik, cara ini dinilai kurang efisien dan efektif dalam mengginaktifkan enzim polifenol oksidase. Proses ini memungkinkan terjadinya reaksi oksidasi katekin oleh enzim polifenol oksidase karena penetrasi panas tidak mampu mengginaktifkan enzim polifenol oksidase secara keseluruhan. Kerugian lain dari cara ini adalah kadar katekin teh hijau relatif rendah, dan dihasilkannya warna teh yang kehitaman. Warna teh yang demikian menunjukkan terdegradasinya klorofil menjadi feofitin.

Untuk mengatasi hal ini, maka perlu dikaji suatu cara lain yaitu proses steaming. Pemberian uap panas pada daun pucuk teh dapat menginaktivasi enzim polifenol oksidase lebih efektif dibandingkan dengan cara panning (yang dilakukan selama ini). Hal ini terjadi karena proses steaming memiliki keunggulan, yaitu: dapat menghindari kontak dengan oksigen karena sistem terlingkupi oleh steam, warna teh yang dihasilkan lebih kehijauan (kandungan klorofil masih tinggi), warna seduhan air teh lebih terang (hijau kekuningan), dapat menghindari penurunan suhu dan penetrasi panas ke dalam sitoplasma lebih efektif (inaktif enzim polifenol oksidase pada bagian sitoplasma dengan senyawa katekin yang berada pada bagian vakuola), sehingga kadar katekin teh hijau yang dihasilkan lebih tinggi.

Untuk itu perlu ditelaah sistem pemroses inaktivasi enzim polifenol oksidase dengan menggunakan steaming, sehingga diperoleh produk teh hijau dengan kadar katekin tinggi. Kajian sistem pemroses ini melibatkan variabel- variabel persen uap panas yang digunakan, kapasitas daun teh dan spray uap air. Parameter yang akan diamati adalah temperatur sistem, kadar katekin, kadar air, dan kelembaban sistem proses yang merupakan fungsi waktu.

\section{METODE PENELITIAN}

Bahan Penelitian. Bahan utama untuk penelitian berupa daun teh yang diperoleh dari Kebun Teh PT. Rumpun Sari MediniLimbangan Kendal. Bahan-bahan kimia untuk keperluan analisa diperoleh dari PT. Bratachem Semarang.

Peralatan Penelitian. Peralatan yang digunakan dalam penelitian adalah alat steam mini dengan mesin penggiling CTC. Alat tersebut dilengkapi dengan termokopel yang dihubungkan dengan sebuah pencatat (multipoint recorder) serta alat pencatat waktu. Alat steam mini ditunjukkan pada Gambar 1. Prinsip kerja alat steam mini adalah inaktivasi enzim polifenol oksidase dengan uap panas dalam suatu panel vertikal dengan bagian pemasukan dibagian atas. Daun jatuh ke bawah karena gaya gravitasi dan dorongan ulir. Sementara uap panas didistribusikan dalam panel dari sebuah boiler.

Peralatan yang digunakan untuk analisa kadar air adalah oven. Alat High Performance Liquid Chromatography (HPLC) digunakan untuk keperluan analisa katekin. Higrometer digunakan untuk mengukur kelembaban sistem. Peralatan lain yang digunakan adalah cawan kecil, erlen meyer, pipet, buret, labu ukur, serta timbangan analitis.

Variabel Proses. Variabel penelitian yang divariasikan adalah laju alir uap panas, temperatur steaming dan spray uap air. Laju alir uap panas ditetapkan pada 40, 50, 60 dan 70\% 
bukaan kran uap panas. Sedangkan temperatur steaming daun teh ditetapkan pada rentang 70 $110{ }^{\circ}$ C. Spray uap air ditetapkan berdasarkan kebutuhan kelembaban sistem yaitu 50, 60, 70 dan $80 \%$.

Prosedur Penelitian. Pucuk daun teh segar dimasukkan kedalam steam mini dan dipanaskan dengan uap panas dengan tujuan menginaktifkan enzim polifenol oksidase pada berbagai variabel. Proses inaktivasi berlangsung selama waktu tertentu. Sampel tiap interval 2 menit diambil, dan diukur kadar katekin serta kadar airnya. Selain itu sistem pemroses diukur temperatur dan kelembabannya.

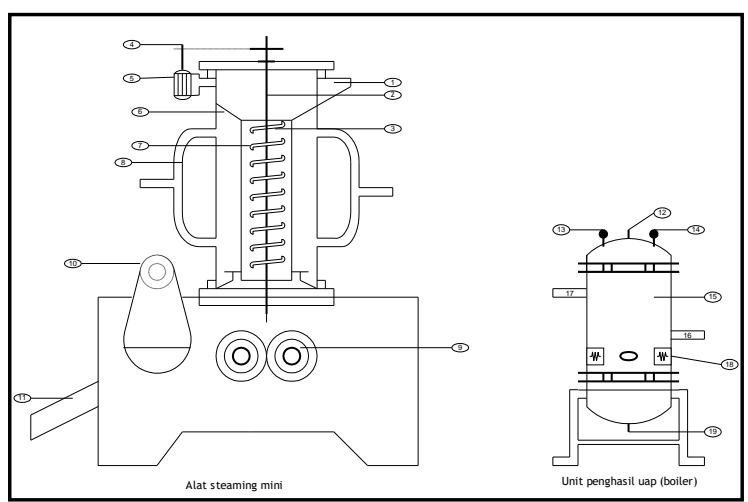

Gambar 1. Alat steam mini dan unit penghasil uap (boiler)

\section{Keterangan gambar:}

1. Corong pemasukan pucuk

2. Sumbu pemutar

3. Spiral pendorong pucuk

4. Pully penggerak

5. Motor penggerak

6. Tabung mesin

7. Tabung pucuk

8. Pipa pembagi/pemasukan uap panas

9. Penggiling pucuk

10.Penggerak mesin CTC

11.Corong
pengeluaran
12.Peluit pengontrol
uap
13.Manometer
14.Termostat
15.Tabung uap
16.Input air
17.Output uap panas
18.Burner
19.Kran penguras

\section{HASIL DAN PEMBAHASAN}

Proses steaming pucuk daun teh bertujuan untuk menginaktifkan enzim polifenol oksidase yang berada dalam sitoplasma, sehingga dihasilkan produk teh hijau berkatekin tinggi. Sebagai penghasil uap panas untuk proses steaming menggunakan boiler bertujuan agar uap panas berpenetrasi ke dalam daun teh. Untuk itu perlu dilakukan setting reaktor inaktivasi enzimatis ke boiler. Pemasangan dan setting alat steaming ke boiler bertujuan untuk merangkai alat proses, sehingga dapat digunakan untuk mengukur data percobaan steaming daun teh. Uji coba alat proses digunakan untuk menstabilkan setting kondisi operasi, konsistensi proses dan stabilitas proses, sehingga dapat digunakan untuk mengukur data percobaan di laboratorium.

Modifikasi alat steaming dimaksudkan untuk mencapai efisiensi dan efektifitas proses, sehingga dihasilkan teh hijau dengan kadar tinggi. Steaming menggunakan screw conveyor menyebabkan pucuk daun teh terpadatkan, akibatnya penetrasi panas yang terjadi tidak merata. Uji coba alat proses termodifikasi digunakan untuk menstabilkan setting kondisi operasi, konsistensi proses dan stabilitas proses dengan menggunakan chain conveyor, sehingga dapat digunakan untuk mengukur data percobaan di laboratorium.

\section{Pengaruh Temperatur}

Studi pendahuluan dilakukan dengan tujuan untuk menentukan temperatur yang relatif baik pada proses steaming daun teh. Temperatur ini divariasikan pada rentang $70-110 \quad{ }^{\circ} \mathrm{C}$ berdasarkan jurnal-jurnal atau publikasi yang sudah ada. Hasil telaah laboratorium tersaji pada Gambar 2. Hasil ini menunjukkan bahwa pada temperatur $90{ }^{\circ} \mathrm{C}$, diperoleh katekin dengan kadar relatif tinggi. Hal ini terjadi karena uap panas akan berpenetrasi relatif cukup efektif ke dalam sitoplasma daun teh, sehingga sebagian besar enzim polifenol oksidase diperkirakan mengalami inaktivasi dan tidak dapat 
mengkatalisa oksidasi aerob katekin. Oleh karenanya, pada saat terjadi kerusakan sel, katekin yang berada dalam vokuola tidak akan teroksidasi menjadi theaflavin dan thearubigin. Pernyataan ini sesuai dengan yang diungkapkan oleh Robert, 1961; Robert, 1962; Bokuchava dan Skobeleva, 1969; Graham, 1992; Yamanishi, 199; bahwa katekin yang teroksidasi dapat mengalami kondensasi membentuk suatu variasi senyawa kompleks, salah satu yang utama (dominan) selanjutnya disebut theaflavin dan thearubigin.

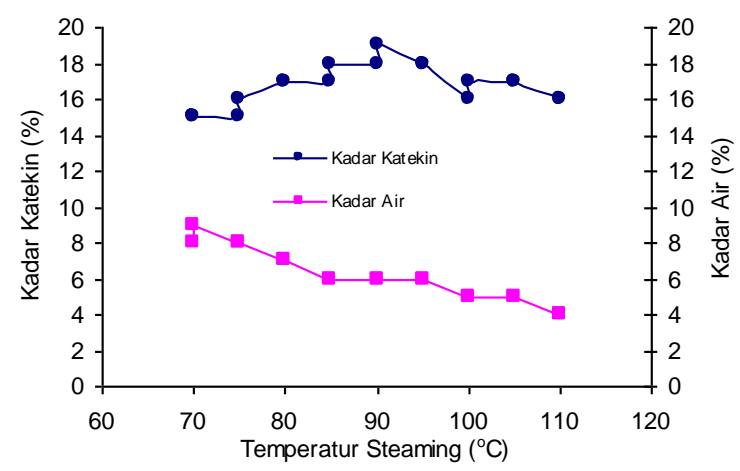

Gambar 2. Pengaruh Temperatur Steaming terhadap Kadar Katekin dan Kadar Air

Reaksi oksidasi enzim polifenol dengan katekin disajikan pada Gambar 3. Lebih lanjut katekin teroksidasi dengan sendirinya menjadi unsur oksidasi yang sangat kuat yang dapat menyebabkan oksidasi non enzimatis substansi pucuk. Secara kuantitatif dapat dikatakan bahwa pembentukan theaflavin dan thearubigin merupakan reaksi terpenting yang terjadi selama oksidasi enzimatik polifenol teh, tetapi oksidasi substansi lain oleh katekin yang teroksidasi merupakan kemungkinan penting yang pokok dalam menentukan kualitas teh olahan (James et al., 1948; Trautner dan Robert, 1950; Popov, 1956; Graham, 1992; Yamanishi, 1995).
Hal tersebut sesuai dengan persamaan Arrhenius yang menyatakan hubungan aktivitas terhadap temperatur, yaitu:

$$
A=A_{o} \cdot e^{\left(-\frac{\Delta E_{h}}{R T}\right)}
$$

Dalam hubungan ini, A adalah aktivitas enzim polifenol pada saat temperatur $\mathrm{T}, \mathrm{A}_{\mathrm{o}}$ adalah aktivitas enzim polifenol saat temperatur acuan, $\Delta \mathrm{E}_{\mathrm{h}}$ adalah energi aktivasi reaksi oksidasi katekin, $\mathrm{R}$ adalah temperatur gas, dan $\mathrm{T}$ adalah temperatur proses penetrasi uap panas dengan enzim polifenol ke dalam sitoplasma. Peningkatan temperatur akan menyebabkan penurunan aktivitas katalitik enzim polifenol oksidase. Pada temperatur $80{ }^{\circ} \mathrm{C}$, enzim mulai menunjukkan penurunan aktivitas dan menurun tajam pada temperatur $90 \quad{ }^{\circ} \mathrm{C}$. Hal ini membuktikan bahwa persamaan Arrhenius ini dibatasi oleh peristiwa denaturasi enzim. Suhu yang terlalu tinggi dapat menyebabkan terjadinya kerusakan struktur enzim. Akibatnya enzim menjadi inaktivasi dan proses oksidasi katekin menjadi terhambat. Akan tetapi, kenaikan temperatur lebih lanjut akan menyebabkan uap panas menembus dinding membran tonoplas, akibatnya katekin yang berada dalam vakuola akan berpenetrasi dengan uap panas, sehingga menyebabkan degradasi termal katekin membentuk senyawa theaflavin dan thearubigin.

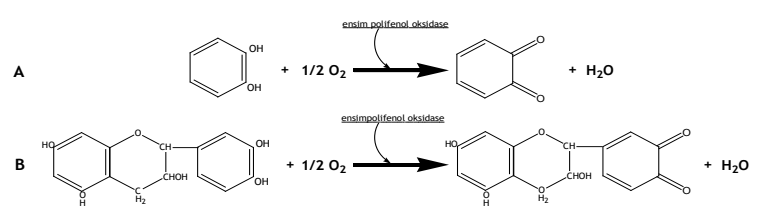

Gambar 3. Diagram oksidasi (A) polifenol dan (B) katekin oleh enzim polifenol oxidase

\section{Pengaruh Kelembaban Sistem}


Data percobaan ini diukur setelah proses steaming dan proses pengeringan. Proses Steaming dilakukan pada berbagai variabel sesuai rancangan proses. Sedangkan proses pengeringan dilakukan pada temperatur $100{ }^{\circ} \mathrm{C}$ selama 3 jam. Hasil pengukuran tersaji pada Gambar 4 dan Gambar 5.

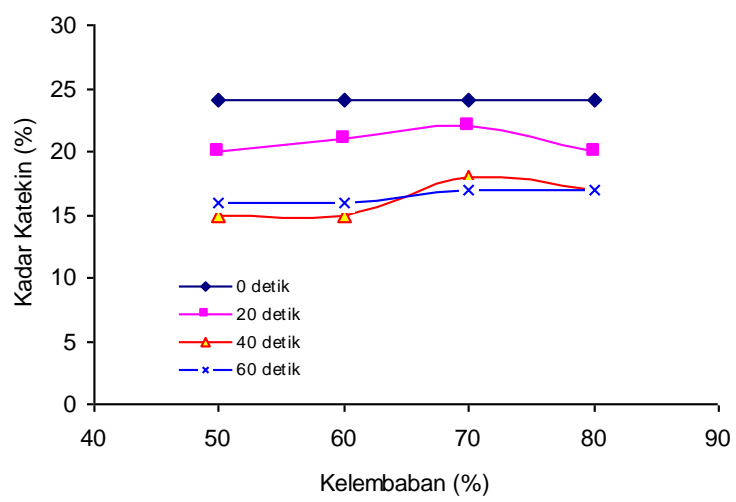

Gambar 4. Pengaruh Kelembaban Terhadap Kadar Katekin pada suhu $90^{\circ} \mathrm{C}$

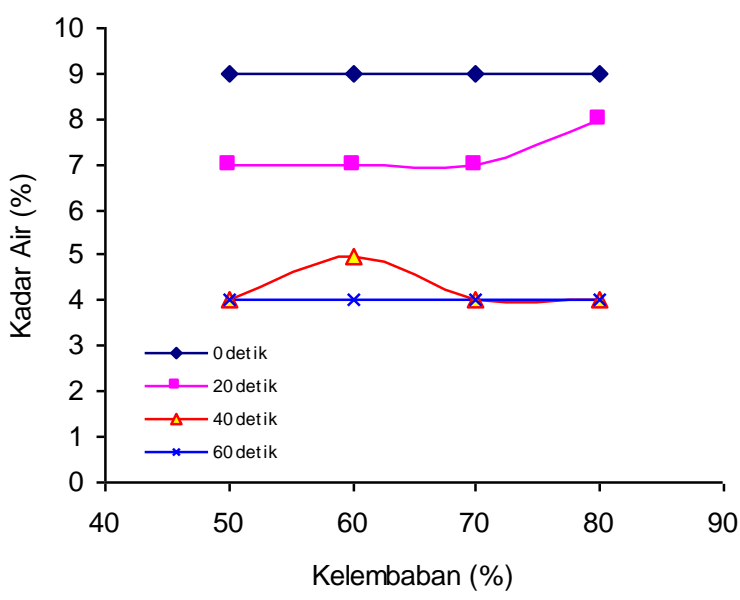

Gambar 5. Pengaruh Kelembaban Terhadap Kadar Air pada suhu $90^{\circ} \mathrm{C}$

Gambar 4 dan 5 menunjukkan bahwa kelembaban $70 \%$ didapatkan kadar katekin relatif tinggi dengan kadar air relatif rendah. Hal ini terjadi karena pada kelembaban terlalu rendah menyebabkan sebagian enzim polifenol mengkatalisis oksidasi aerobik katekin. Akibatnya katekin akan terkonversi menjadi senyawa theaflavin dan thearubigin. Fenomena ini dimungkinkan karena sistem kurang terlingkupi oleh uap panas, sehingga oksigen akan lebih leluasa kontak fasa dengan enzim polifenol. Meskipun demikian, jika sistem terlalu banyak terlingkupi oleh uap panas, maka pada saat proses pengeringan menyebabkan beban uap air yang akan dilepas menjadi lebih berat, sehingga kadar air teh hijau yang dihasilkan relatif tinggi.

\section{KESIMPULAN}

Hasil proses steaming daun teh menunjukkan bahwa pada temperatur $90{ }^{\circ} \mathrm{C}$, diperoleh katekin dengan kadar relatif tinggi. Hasil kajian juga menunjukkan bahwa kelembaban $70 \%$ didapatkan kadar katekin relatif tinggi dengan kadar air relatif rendah.

\section{UCAPAN TERIMA KASIH}

Pada kesempatan ini, penulis mengucapkan syukur Alhamdulillah kepada Allah SWT serta terima kasih yang sebesar-besarnya kepada Kementrian Negara Riset dan Teknologi atas dukungan dana penelitian ini.

\section{DAFTAR PUSTAKA}

Ariwibowo, D., Yulianto, M.E., \& Arifan, F., 2005,'Kajian perpindahan panas proses steaming inaktivasi enzim dalam pengolahan teh hijau", Majalah Teknik, tahun ke XXV, Edisi 2, hal 103-108, ISSN: $0852-1697$.

Bailey, J.E., \& Ollis, D.F. 1986. Biochemical engineering fundamentals. McGraw-Hill Book Company. United States of America.

Bambang, K., T. Suhartika., Supria, dan Tanjung, S. 1996. Katekin pucuk teh segar dan perubahannya selama pengolahan. Hasil Penelitian dan Pengembangan Teknik Produksi dan Pasca Panen Teh dan Kina. TA. 1995/1996.

Bambang,K., Abas, T., Affandi, A., Sumantri, S., dan Suryatmo, F. A. 2000. Rancang bangun proses teh hijau berkadar katekin tinggi. Laporan Akhir. Proyek Pengkajian 
Teknologi Pertanian Partisipatif. Gambung.

Bhatia, I. S. 1963. Chemical aspect of green leaf processing. Two and a Bud. 10(2). 28-33.

Bhirud, P. R., \& Sosulski, F. W. 1993. Thermal inactivation kinetics of wheat germ Lipoxygenase. Journal of Food Science, 58. 1095-1098.

Campos, C. F., Souza, P. E. A., Coelho, V., \& Gloria, M. B. A. 1996. Chemical composition, enzyme activity and effect of enzyme inactivation on flavor quality of green coconut water. Journal of Food Processing and Preservation, 20. 487-500.

Chen, J. 1991. The inhibitory effects of Chinese tea in the occurence of Esophageal Tumor on Rath Induced by NMN2 A. Ibid.

Daemen, A. L. H. 1981. The destruction of enzymes and bacteria during spray drying of milk and whey. 1. The thermoresistance of some enzymes and bacteria in milk and whey with various total solids contents. Neth. Milk Dairy J., 35. 133-44.

Erkmen, O. 2000. Inactivation kinetics of Listeria monocytogenes in Turkish White cheese during the ripening period. Journal of Food Engineering, 46. 127-131.

Fujiki, H. 1991. Anti carcinogenic effects of (-)epigallocatechin gallate (EGCG). Ibid.

Fung, L. C. 1991. The effect of tea and its components on lung tumorgenesis induced by tobacco-specific mitrosamine. Ibid.

Graham, H. N. 1992. Green tea composition, consumption, and polyphenol chemistry. Preventative Medicine, 21. 334-350.

Gregory, R., \& Bendall, D. 1966. The purification and some properties of polyphenol oxidase from tea. Biochem. J. 101. 569-581..

Hayatsu, H. 1991. Antimutagenic effects of tea polyphenols. Int. Symp. Phys and Pharm. Effects of C. sinensis. New York. 3-5 March 1991.

Senen. Yulianto, M. E. \& Ariwibowo, D. 2006. Model Perpindahan Panas Teknologi Steaming Proses Inaktivasi Enzim Polifenol Oksidase Dalam Pengolahan Teh Hijau Berkatekin Tinggi, Laporan Sementara Penelitian Fundamental DIKTI. www.freepatentsonline.com/4613672.

www.freepatentsonline.com/7012149

Yulianto, M.E., Ariwibowo, D., Arifan, F., Kusumayanti, H., Nugraheni, F.S., Senen., 2006,"Model Perpindahan Massa Proses Steaming Inaktivasi Enzim Polifenol Oksadase Dalam Pengolahan Teh Hijau", Jurnal Gema Teknologi, Volume 15 Nomor 2, September 2006, ISSN: 0852-0232. 